\title{
Erratum to: Intersectoral mobility of researchers in Russia: trends and policy measures
}

Irina Dezhina

Correspondence: i.dezhina@skoltech.ru

Skolkovo Institute of Science and Technology, 100 Novaya str. Skolkovo, Odintsovsky District, 143025 Moscow Region, Russia
After the publication of this work (Dezhina 2015), we noticed an error in the Russian abstract. In every instance of the word "межотраслевая" it should be changed to "межсекторальная". The financial statement was missing from the Acknowledgements. The corrected statement is provided below:

\section{Acknowledgements}

The research was supported by the grant from the Russian Foundation for Humanities (grant no. 13-03-00089).

Received: 30 November 2015 Accepted: 30 November 2015

Published online: 08 December 2015

\section{Reference}

Dezhina I (2015) Intersectoral mobility of researchers in Russia: trends and policy measures. Triple Helix 2:6
Submit your manuscript to a SpringerOpen ${ }^{\odot}$ journal and benefit from:

- Convenient online submission

- Rigorous peer review

- Immediate publication on acceptance

- Open access: articles freely available online

- High visibility within the field

- Retaining the copyright to your article

Submit your next manuscript at $>$ springeropen.com 